\title{
THE INDUSTRIALIZATION OF KOREA'S PERFORMING ARTS AND ITS PATH FOR GLOBALIZATION
}

\author{
Man-Soo Cho \\ Chungbuk National University \\ mscho@chungbuk.ac.kr
}

\begin{abstract}
This study examines whether Korea's performing arts has the potential to create a Korean Wave, as K-Pop and K-drama have, and the shape in which such potential may take form. Korea's performing arts underwent industrialization from the 1990s and into the 200os, expanding its capacities for creativity, production, and distribution. Here, industrialization includes not only that of the commercial domain but also of the artistic domain, and this study reviews the process and shape of the industrialization in both domains. From the late 20oos, Korean musical theater and nonverbal performances saw a growth in their activities in overseas markets. However, the performing arts differs from other genres, such as TV drama or popular music, in that the creator uses the performance hall and performers as the medium to reach the consumer. For long-running and licensed productions, the market needs to reach a level of maturity in terms of human resources, performance space, and market conditions. As Japan is the only country in Asia whose market satisfies this requirement, it will be necessary for the industrialization of the performing arts to occur in the other countries in Asia, particularly in China and the ASEAN countries, for Korea's performing arts to create a Korean Wave in this region.
\end{abstract}

\section{Keywords}

Hallyu; industrialization; Korean Wave; musical theater; performing arts

\begin{abstract}
About the Author
Man-Soo Cho is a Professor at the Department of French Language and Culture at Chungbuk National University. His teaching and research interests fall in the field of drama and performing arts. As the Editorial member of The Association of the French Culture and Art (2013 ) and The International Association of Comparative Korean Studies (2016 ), he has published several articles including "Dramatic and Narrative Structure of French Musical Comedy" (2008), "Composition of Drama and Music in Les Misérables" (2016). He was the Dramaturg of Namsan Art Centre (2012-2016) and is the incumbent Literary Manager at the Korea National Company (2018).
\end{abstract}




\section{INTRODUCTION}

Since 2010, "culture" became an important keyword in Korea's political slogans. That is, along with economic development and democratization, which has so far been the two pillars of modern Korean history, raising the quality of life through culture gained the position as a key issue for Korean society. During its term from 2013 to 2016, the Park Geun-hye administration used the terms "creative economy" and "cultural enrichment" as its core policy direction. These terms represent the administration's attempt to bring the economy and the growing desire for cultural enjoyment together in the effort to develop Korea's culture industry. Furthermore, they reflect not only the increase in the domestic demand for cultural entertainment but also the surge in the global market's demand for Korean culture, which is known as the "Korean Wave (Hallyu)." Unsurprisingly, the Moon Jae-in administration that came to power in 2017 also set the global expansion of the Korean Wave as one of its key tasks.

The Korean Wave first hit the Asian market as Korean films, pop music, and TV dramas became explosively popular, then extended its reach to Europe and the Americas. However, Korea's performing arts have yet to enjoy similar expansion, largely due to the fact that the performing arts entirely differs in their characteristics from films, pop music, and TV dramas. While the latter genres are put into mediums such as images or recordings that enable easy market transactions, performances cannot be commercialized as records on media but must be distributed in live formats. Will it be possible for Korea's performing arts to enter the global market as the other genres of the country's culture industry have? Moreover, if so, in what shape will such globalization happen? The goal of this research is to provide answers to these questions.

Due to the live format of the performances, the export of performing arts productions requires specific considerations. To export a performing arts production, a considerable amount of the goods and items needs to be transferred overseas. The market for the performing arts in the receiving or importing country also needs to be sufficiently large to support long-term performances for the performance to be profitable. Long-term overseas performances may take the form of taking the original cast and staff to the overseas venue or selling the copyrights and having a production company at the receiving country produce the performance locally. Therefore, the country of import must already have a certain level of performing arts consumption capacity as well as production capacity. Since finding overseas markets that satisfy these requirements must precede the export of any performance, it is relatively more challenging for the performing arts genre to create a Korean Wave than other cultural genres. 
Another characteristic of the performing arts sector is the close association between its pure and commercial domains. These two areas come together to generate synergy. In the case of music, there is little correlation between the development of classical music and that of popular music, but in the field of performing arts, the pure and commercial domains develop together as they share many physical foundations such as actors, directors, stage art, music, and lighting. In this sense, the industrialization of the performing arts ultimately refers to the creation of an ecosystem that sustains the co-existence of its pure and commercial domains. Therefore, this study adopts the broad understanding of the term "performing arts" that includes both its pure and commercial forms, despite that musicals and nonverbal performances are the main areas in the field of performing arts that are relevant to the Korean Wave, based on the perspective that the development of non-commercial, pure performing arts provides the foundation for commercial performances.

This study first examines the process through which Korea's performing arts has become industrialized domestically. In the early 2000 shen Korea's performing arts sought to enter the global market, what kind of changes were taking place in the field within Korea? As the industrialization progressed, how did the division of labor take place, and what was the shape that the ecosystem of the performing arts took? What are the changes that happened in the way the performances are produced, distributed, and consumed? How do the performing arts stand apart from other cultural genres in terms of international exchanges and entry into the global market? By answering these questions, this research presents observations on how Korea's performing arts field progressed amid the globalization of Korean culture, broadly referred to as the Korean Wave, and suggests the shape of its future direction. This study differs from previous studies, which have mostly dealt with the overseas market entry strategies of Korea's musical theater, by analyzing and presenting novel insights into the industrialization of Korea's performing arts field as a whole.

\section{THE EARLY STAGE OF INDUSTRIALIZATION IN KOREA'S PERFORMING ARTS}

The key symbol of Korea's performing arts is the cultural district called "Daehak-ro ('daehak' meaning university and 'ro' meaning street)." Daehak-ro refers to an area in Seoul with a high concentration of performance halls and theaters, similar to New York City's Broadway and London's West End. As of 2016, Daehak-ro was home to 123 performance halls and theaters (KAMS, 2017 Survey on the Performing Art 33) and its characteristics compact the scenery of Korea's performing arts field. First of all, as the name "Daehak-ro" suggests, this area is a gathering place for young university 
students. That a gathering place for young students is the center of performing arts reflects how the main consumers of Korea's performing arts are university students or people in their twenties. Another characteristic of Daehak-ro is that the theaters here are mostly small-scale. As of $2010,70 \%$ of the theaters in Daehak-ro had less than 200 seats (Ahn, "A Statistical Look" 9). The creative unit that leads most of the performances in these small theaters is composed of theatrical groups. As of 2010, a total of 752 productions were performed at 112 theaters, including 502 plays, 97 musicals, and 153 music and traditional performances; and among the plays and musicals, 50\% were premiere performances. In 2010, Daehak-ro recorded a sales revenue of 340 billion Korean won in the Korean performing arts market, which was estimated to be about 500 billion Korean won.

As a creative incubator for small-scale productions, Daehak-ro simultaneously represents the creative dynamism of Korea's performing arts industry and its small production scale. In short, Daehak-ro is Korea's Off-Broadway. The dynamism of Daehak-ro comes from being the training ground for actors and playwrights, the fundamental creative agents of performing arts, by presenting opportunities to perform and create various works. With Daehak-ro providing an environment where the actors who have completed their training from about 80 universities in Korea that have theater- or acting-related majors can find consistent opportunities to perform on stage, albeit in small-scale productions, Korea's theater scene was able to accumulate a significant amount of human resources. The theaters in Daehak-ro operate under a system where they rent out their spaces to theatrical groups for individual productions without running a fixed annual program. In other words, the theaters are closer to the concept of properties with rentable spaces rather than a distribution channel. Under this system, theatrical groups as creative units need to find their consumers, that is, the audience, directly without any mediator in distributing their performance, and as such, the burden of both production and sales is on the shoulders of the creator.

However, Daehak-ro, which had begun to form in the early 1980s, underwent a significant change from the mid-199os. This change was not limited to Daehak-ro but also reflected a change in Korea's performing arts scene as a whole. Korea's performing arts field had finally begun to take the shape of a culture industry. Until the 1980s, the freedom of expression in Korea was oppressed by the country's authoritarian government, limiting the themes and topics that can be put into performances, but as democratization opened doors for the free expression of imagination without restrictions, Korea's capacity for creativity doubled in the cultural domain. The economic vitality of the early 1990s also helped to create a demand for cultural products and stimulated investment in this area. At the same time, the normalization of the Korea-China relations in 1992, China's economic reforms, and Korea's lifting of the censorship on Japanese popular culture in 1998 
made it possible for Korea's culture industry to enter the global market. These broad social and cultural changes created a new trend in the domestic market for films, pop music, and TV dramas, prompting Korean pop culture contents to enter into overseas markets and give birth to the phenomenon known as the Korean Wave.

To understand what gave rise to this phenomenon, it is necessary to be atentive to the changes in Korea's creative environment. While the culture industry had centered on creative artists and a small-scale production system that supported them in the past, in the 1990s, there began to emerge professional production companies. The film industry started to move away from the existing film production methods to produce movies that were specifically designed to meet consumer demands, starting with Wedding Story in 1992. As a result, the blockbuster Shiri hit the theaters in 1999 and became the first Korean film to bring in 10 million audiences to movie theaters. The popular music industry started to show signs of change in 1992 with the advent of the dance group Seo Taiji and Boys and, with the establishment of large entertainment companies such as SM Entertainment in 1995, JYP Entertainment in 1997, and YG Entertainment in 1999, K-pop grew into a global genre.

Although on a smaller industrial scale, a similar phenomenon can be observed in the performing arts as well. Up to the 1980s, there was no distinction in the entities that staged artistic productions and those who staged commercial productions. In other words, theatrical groups producing experimental and absurd performances also staged commercial plays and even musicals. Until the 1980 or oarly 1990 , the producers of theater productions were mostly theatrical groups, that is, groups comprised of creative artists. The head of production was the executive director of the theatrical group, and the planning and production staff consisted of the theatrical group's actors who were not playing parts on stage in the specific production.

However, in the mid- to late 1990s, professional performing arts production companies began to appear. These production companies focused their attention on popular and commercial successes rather than on artistic achievements and experimentation. The performing arts scene with previously blurred boundaries between the artistic and the commercial had finally begun to separate its commercial domain, leading to a growth in the scale of productions and the diversification of distribution channels. Papa Production, founded in 1996, produced Liar, which holds the record for the largest accumulated number of audiences as a play since its first staging in 1998. AGA Company, which produced translated versions of overseas commercial performances including Closer, Proof, and Art, was also founded in 1998. The first performance of Nanta, the non-verbal performance that 
became one of the works that symbolize Korea's culture industry, was first put on stage in 1997 by PMC Production.

Meaningful changes can also be detected in the field of musical comedy around this period. In 1989, Lotte World Art Theater declared itself as a professional theater company. In 1994, Seensi Company, which had been staging both plays and musicals, announced its transformation into a professional musical production company. Acom, a professional musical production company, was established in 1991 and premiered The Last Empress in 1995 which brought more than a million audiences to the theater. It was in 1996 that the Samsung Entertainment Group, a subsidiary of Samsung Corporation, jumped into the musical theater business, starting with the licensed production of 42 nd Street. As such, the 1990 os can be defined as the early industrialization period of Korea's musical theater and, at the same time, of Korea's performing arts and culture industry as a whole.

In the 2ooos, Korea's performing arts experienced another change. On the one hand, commercial productions saw further development. The Best Plays, a project which put together the popular plays of the 1990 os in one season, saw commercial success in 2004, leading to the establishment of The Best Plays Co. Ltd. By 2008, more than a million audiences had visited the theater to see The Best Plays. Production company Soohyunjae, established in 2013, also aggressively staged commercial productions that cast TV and film stars and expanded the base of theatergoers to include middle-aged audiences. Meanwhile, the most important change in the performing arts field that happened during this period is the increase in the proportion of public theaters. Public theaters, usually known as cultural art centers in Korea, had so far been inactive in producing and distributing performances but around this time, they began to take on a meaningful function in these areas. The year 1996 saw the establishment of the Korean Cultural \& Art Centers Association. In the past, public cultural art centers in municipalities and towns had only served as spaces for one-time events or as rentable spaces. However, responding to the citizens' rapidly increasing cultural demands, the cultural art centers came to be recognized as places that should provide cultural contents to citizens on a yearround basis.

As a result, cultural art centers began to function, though weakly, as a distribution channel that connects the audience, who are consumers, and the creators of performing arts productions. Thus, the productions produced in Daehak-ro slowly began to spread through the nationwide distribution networks based on culture and arts centers. In this process, there rose awareness of the need for a performing arts market for discovering high-quality performing arts contents suitable for cultural arts centers. The Performing Art Market in Seoul (PAMS) and the Jeju Haevichi Art Festival were established in 2005 and 2007, respectively, to respond 
to this need. However, municipal cultural art centers were mostly medium-to-large capacity, whereas most of the productions born at Daehak-ro were geared to smallcapacity theaters. In this sense, the creative entities and the distribution channel had yet to be streamlined.

While cultural art centers expanded the distribution and consumption of performances, the public theaters whose role was to produce performances also became greater. In 2006, the Arts Council Korea, which had been managing the culture and arts center in Daehak-ro, restructured the center as the independent Arko Theater to activate its function as a producing house. Myeongdong Theater and Namsan Art Center opened in 2009, and in 2010, the Korea National Theater, which stages a wide range of performances from traditional music and traditional drama to modern drama, established an independent theater company called the National Theater Company of Korea, with its separate theater and started producing a significantly larger number of stage productions. Not only did the number of plays produced by public theaters increase but also those by private theaters operated by the cultural foundations under corporations. The LG Art Center opened in 2000, and Doosan Art Center, which had mainly rented out its spaces, started to engage actively in producing plays from 2007.

The government support system for individual performing arts productions also experienced a change. The previous government funding, amounting to about 20-30 million Korean won per production, was not so much for upgrading the quality of performing arts productions but more for sustaining the creative activities of artists. However, the Creative Factory project, implemented under the direction of the Ministry of Culture, Sports and Tourism since 2008, recognizes stage productions as cultural products and not just as a result of artistic creation, as the use of "factory" in its name suggests. The available funding for the performing arts also increased to 100-150 million Korean won per production, with the aim to create industrialized contents in the performing arts field.

As illustrated so far, in the 2ooos, there was a growth in the number of producing houses that created more productions scaled for medium and large theaters, as opposed to small theaters, and a distribution network for the performances had formed, centering on the local culture and art centers. There were more producers responsible for programming and producing performances in public theaters, culture and art centers, and professional production companies. This larger pool of human resources involved in the industrialization of the performing arts is reflected in the establishment of the Korea Association of Performing Arts Producers in 2004. In 2004, the Ministry of Culture, Sports, and Tourism announced the "New Arts Policy for the 21st Century" and started its full-fledged promotion of policies for the arts industry (KAMS, Report on the Future Strategy 10). Also, in 2006, to 
realize the policies into concrete practices, the Korea Art Management Service was established with the mission to "promote the distribution of the arts" and "advance competitive arts organizations into the world" (Korea Art Management Service). In other words, the new goal set for Korea's performing arts was to revitalize the domestic performing arts industry while distributing the outcomes of such efforts in the global market.

\section{THE SHAPE OF INTERNATIONALIZATION}

Today, it is not such a leap to discuss the potential of Korea's performing arts to enter the global market amid the currents of the Korean Wave. However, until the early 1990s, it was difficult for Korea's performing arts to find opportunities for international cultural exchanges, let alone contemplate entering into the global market. Until the early 1990s, Korea had a ban on the import of Japanese pop culture, and the country's diplomatic relations with China had yet to be normalized. In the case of Southeast Asia, there was not only geographical distance but also a cultural difference, as Southeast Asian countries do not share the Confucian traditions of East Asia, which made it difficult to find cultural connections. Korea, a divided nation, was practically a culturally isolated island.

This situation began to change in 1992 with the normalization of the KoreaChina relations. The BeSeTo Theater Festival, a festival of plays from China, Korea, and Japan which was held in Seoul for the first time in 1994, marked the beginning of Korea's international performing arts exchange with its neighboring countries. The International Theater Institute's Seoul Congress in 1997 created the momentum for Korea to host the Theater of Nations with 27 participating countries. The 1997 Theater of Nations opened the eyes of the Korean audience and thespians to the trends and quality of performances around the world. Furthermore, the experience of preparing a large-scale international theater festival allowed domestic producers and production staff to acquire the know-how on international cooperation and secure a global network for collaboration.

Utilizing this network, the Seoul Theatre Festival was able to stage the works of world-famous masters such as Robert Wilson, Lee Breuer, and Giorgio Strehler in 1999 and 2000. In 2001, Seoul Theater Festival transformed into the Seoul Performing Arts Festival (SPAF), renewing not only its name but also its system, to bring in greater participation of international performances and open its doors to multiple genres beyond plays or dance performances. It was also the mid-2ooos that Korea began to hold international street arts festivals such as Gwacheon Festival and Ansan Street Arts Festival. However, despite the formation of international 
exchange platforms in the form of festivals, most of the foreign teams participating in domestic festivals were not from neighboring Asian countries but European countries. The reason is that Asian countries had traditional performances but lacked modern performing arts repertoires to introduce abroad.

In addition to promoting the participation of foreign performances in domestic festivals, policies to support Korean performances to go abroad were also strengthened. Seoul Art Market, established in 2005, is a market for taking domestic performances to the international stage. Seoul Art Market presents the PAMS Choice, which showcases various performances. Around ten performances from theater, dance, music, and multi-genres are selected as PAMS Choice to be performed in front of an audience. These performances include many performing arts producers from abroad, becoming a chance for these performances to gain invitations to perform overseas. From 2005 to 2014, a total of 150 performances were showcased at the PAMS Choice, and these performances received a total of 827 invitations to perform overseas.

Table 1. Overseas Invitations Received by Performances Showcased at the PAMS Choice (Years 2005-2014)

\begin{tabular}{|c|c|c|c|c|c|c|c|c|c|c|c|}
\hline Year & 2005 & 2006 & 2007 & 2008 & 2009 & 2010 & 2011 & 2012 & 2013 & 2014 & Total \\
\hline $\begin{array}{l}\text { Number of } \\
\text { performances } \\
\text { showcased } \\
\text { at the PAMS } \\
\text { Choice }\end{array}$ & 13 & 29 & 18 & 16 & 15 & 13 & 13 & 13 & 10 & 10 & 150 \\
\hline $\begin{array}{l}\text { Overseas } \\
\text { Invitation } \\
\text { Received }\end{array}$ & 0 & 14 & 86 & 78 & 106 & 110 & 116 & 125 & 131 & 112 & 827 \\
\hline
\end{tabular}

Data Source: Lee, "Research on the Current State of Korean Theatre Companies" 21

The works selected by the PAMS Choice of Seoul Art Market or Center Stage Korea are not necessarily those that have the potential to generate economic profit in the overseas market from the culture industry perspective. The performances of the Yohangza Company, and the performance groups Tuida, Pansori Project Za, among others, which gained the most chances to perform, are considered successful not only in terms of their artistry but also audience mobilization in the domestic market. However, these performances are not suitable for generating profit through short-term overseas performances. Moreover, the goal of these artists and 
artistic groups is to continue their creative endeavors rather than to realize profits by securing long-term contracts for performing one of their works. The Korean government's support system for the international exchange of performing arts does not aim at directly promoting the sales of performances. Instead, its purpose is to enable domestic performances to enter a more extensive ecosystem where they can continue their creative development through a global network.

The international exchanges of fundamental arts such as visual and performing arts can also indirectly contribute to the spread of popular culture products. For this reason, in April 2018, the Korea Culture and Information Service announced that it would expand the Korean Wave, which has so far focused on popular culture, to include the fundamental arts such as visual and performing arts through its "global expansion strategy of Korean culture." This announcement reflects the awareness that the culture industry is the outcome of structuring the artistic and commercial domains into a single ecosystem. Through this awareness, they aim to promote both the international exchange of performing arts and the advancement of Korea's performing arts into the global market at the same time. Furthermore, the Korea Culture and Information Service highlighted the ASEAN countries and Russia as Korea's new partners of cultural exchange to diversify the Korean Wave's regional reach. In the case of the performing arts industry, the ASEAN region does not yet have the necessary market conditions for Korea's performances to enter. The inclusion of this region as a cultural exchange partner shows the recognition that ASEAN countries are important markets to expand Korea's overseas performing arts market, which is currently concentrated in China and Japan, in the long term.

\section{THE ADVANCEMENT OF KOREAN MUSICAL THEATER AND NONVERBAL PERFORMANCES INTO THE GLOBAL MARKET}

Until 1996 when the international copyright treaty came to force under the Berne Convention, the theaters in Korea have put original foreign performances on stage without acquiring their license. However, it was during this period that groups specializing in musical theater started to emerge in Korea, and this experience of staging musicals allowed the country's musical theater to acquire their own knowhow and also form a pool of professional musical actors. The human resources and know-how established during this period became the basis for Korean musical theater to grow in a short time after the copyright treaty came to effect in the $2000 \mathrm{~s}$ when licensed musicals became common and gained popularity. 
It is generally said that it was after the success of The Phantom of Opera produced by Seol \& Company in 2002 that Korea's musical theater market began to grow to a level that befits the description as "industrialization." The Phantom of the Opera's success was a symbolic phenomenon, so much so that it is called the "Big Bang of Korean musical theater" (Choi, "A Study on the Industrialization Strategy" 89). For a nine-month performance, the production invested 17 billion Korean won and earned 19.2 billion Korean won, that is, a profit of 2.2 billion Korean won, and proved to the Korean performing arts market that musical productions are profitable. As a result, start-up investment companies began to take an interest in musical theater, and investment funds were created, establishing an environment for producing large-scale licensed musicals that require over 10 billion Korean won to produce, including Beauty and the Beast, Mamma Mia, and Aida. It was also during this period that many venues dedicated to the musical theater were created, providing spaces for long-term performances. Previously, musical productions were held in the concert halls of public theaters such as the National Theater, the Sejong Center for the Performing Arts, the Seoul Arts Center, etc., which made it difficult to secure a space that can be used for a lengthy period due to the characteristics of public theaters. As it is essential for musical productions to run for a long term to be profitable, this was a very unfavorable situation. Thus, the opening of the Popcorn House (1,200 seats) in 2003, Chungmu Art Hall (800 seats) in 2005, the Charlotte Theater ( 1,200 seats) in 2006, and Woori Art Hall (1,200 seats), D-cube Theater (1,200 seats), and Blue Square (1,700 seats; 1,200 seats) established the basic physical infrastructure for Korea's musical theater industry to bloom.

Amid this situation, Korea's musical theater market continued to grow by more than $20 \%$ every year since 2000 . The 10-billion-Korean-won market in 2000 expanded to 300 billion by 2014 , a 25 -fold growth over 14 years. Now, the size of the Korean musical theater market is about half the size of that of Japan and onefifth of Broadway (Park, A Study 61). Large-scale musical production companies such as Seol \& Company, Seensi Company, OD Musical Company, and Musical Heaven grew by producing large-scale or new overseas musicals under license. Most Broadway and West End's blockbusters, not only the classics but also the latest shows, were licensed and produced in Korea. At times, productions which were relatively unnoticed on Broadway, such as Jekyll and Hyde and Thrill Me, saw fantastic success in Korea after some adjustments to cater to the Korean audiences' taste. Also, musical productions from not only the United Kingdom and the United States but also various other countries including France, the Czech Republic, Germany, and Austria, were imported under license to be produced in Korea. The increase in the staging of licensed musicals gradually saturated Korea's musical theater market. The number of musical productions saw an 8-fold hike in from 50 to 400 over a ten-year period from 2001, while the market only tripled from 
100 billion to 300 billion Korean won, indicating an oversupply (Kim, "A Study on Overseas Expansion" 4).

Meanwhile, in addition to musicals, nonverbal performances also led the industrialization of Korea's performing arts. After witnessing the success of nonverbal performances overseas such as Stump and the Blue Man Group, Korea's performing arts scene gave birth to nonverbal performances that became massive hits, including Nanta (1997), Jump (2003), and Ballerina Who Loved a B-boy (2005). Nanta was the first to open its exclusive theater in Korea. However, the fact remains that both musical and nonverbal productions require a continuous influx of audiences to maintain long-running performances or exclusive theaters, a requirement that cannot be met by the limited size of the Korean market. The domestic audience, mainly consisting of women in their twenties and thirties, is not a large enough pool to sustain the current musical theater market with its oversupply of productions. "Despite the efforts to expand the domestic audience base, in the long term, given the size of Korea's population and its growth trend, the domestic market will have limited capacity to expand, and it will be unlikely for the fast-growing musical industry to secure a sufficient economy of scale as a whole" (Choi and Yim 50).

To overcome this limitation, Korea's performing arts industry faced the need to bring in the overseas audience to the domestic market or find ways for domestic musical productions to enter the overseas market. The first option of increasing the influx of audience from abroad requires tourist audiences, whereas the second option requires taking the production overseas or selling the show's license to foreign theater or production companies. London's West End or New York City's Broadway became the center of musical theater largely thanks to the constant influx of audiences from abroad. The flourishment of musical theater is only possible when there is a balance between the domestic capacity of musical productions and the increase in tourists. Fortunately, in the case of Korea, the development of the performing arts industry and the rapid growth of tourists happened during the same period. "The number of inbound visitors to Korea has been steadily growing, from 6.02 million in 2005, 6.8 million in 2008, 11 million in 2012, 14.2 million in 2014, and 17.2 million in 2017. The continuous increase in tourists visiting Korea since 2004 is due to the growth of Chinese tourists and tourists from Southeast Asia, an emerging tourism market, who come to experience the Korean Wave" (Lee, Analysis 3). As of 2016, the inbound tourists' top ten countries of origin were China, Japan, Taiwan, the United States, Hong Kong, Thailand, Malaysia, Vietnam, Singapore, and the Philippines. Among these nationalities, Chinese tourists accounted for $50.2 \%$, and Japanese tourists for $14.7 \%$, taking up a dominating portion of incoming visitors. 
Another notable fact is that the vast majority of visitors to Korea are from Asian countries. The rise in the levels of income in Asian countries had led to a higher frequency in overseas travels among Asians. Compared to European and American tourists, Asian tourists are already familiar with Korean traditional culture, so they find more interest in enjoying various performing arts productions other than traditional performances. Tickets sales through the global version of Interpark, an online booking website, which provide services for non-Koreans, increased by $102 \%$ in 2012 compared to the previous year. The Visit Seoul website operated by Seoul City also saw an increase of 254\% (Park, "What Happened in the Musical Theater in $2012 " 46)$. In $2016,2,626,358$ foreign visitors (15\%) out of the $17,241,823$ visitors who visited Korea saw performing arts shows, among which $69 \%$ were Chinese, $11 \%$ were Taiwanese, and 5\% were Japanese (2017 Hallyu White Paper 136). The Korea Tourism Organization held the Korea in Motion Festival, a performing arts festival targeting foreign tourists, for ten years from 2005 to 2014 to encourage tourists to attend performances. In this environment, PMC's Nanta surpassed 1 million accumulated foreign audience in 2006 and built additional exclusive theaters in Seoul in Myeongdong in 2009, Hongdae in 2011, and Chungjeongno in 2013 as well as one in Jeju Island in 2017 to cater to the increasing number of Chinese tourists to Jeju. Thanks to the growth in tourist audiences, Nanta's accumulated audience exceeded 10 million by 2014.

Compared to musicals, it is easier for nonverbal performances to enter the global market because of their small scale and lack of language barrier. Nanta and Jump had been produced with the global market in mind from the very beginning. Nanta premiered in 1997, then introduced itself to the global performing arts market through the Edinburgh Festival in 1999. From 2004, Nanta made its way to Broadway, and the show has been running on an open run basis. Nanta also opened an exclusive theater in Bangkok, Thailand in 2013. Jump premiered in 2002 and participated in the Edinburgh Festival since 2004. where the show became the number one show in ticket sales in 2005. Thanks to its good reception in the global market, Jump also secured an open run on Broadway from 2007.

The very first Korean musical production to take its stage abroad is The Last Empress. Acom premiered The Last Empress in Seoul in 1995 and had its first show in New York in 1997. Since then, the show has held several performances in the United States and the United Kingdom, but these instances were not for profit. The New York show of The Last Empress was mainly for the promotion of Korea's national image or cultural exchange, considering the nationalist tone of the musical, while also seeking a marketing effect for the domestic Korean audience. The same applies to Hero, which premiered in 2009 and was staged in New York in 2011. Korean musicals advanced into overseas markets properly after 2012, assisted by the Korean Wave. As shown in Table 2 below, the number of Korean musicals and 
nonverbal performances holding overseas performances increased significantly from 2012.

Table 2. Number of Korean musical and nonverbal productions that entered overseas markets by year

\begin{tabular}{lllllllllllllllllllll} 
Year & 97 & 98 & 99 & 00 & 01 & 02 & 03 & 04 & 05 & 06 & 07 & 08 & 09 & 10 & 11 & 12 & 13 & 14 \\
$\begin{array}{l}\text { Number of } \\
\text { Productions }\end{array}$ & 1 & 1 & 1 & 1 & 1 & 2 & 2 & 2 & 2 & 4 & 7 & 4 & 4 & 2 & 4 & 16 & 29 & 14 \\
\hline
\end{tabular}

Table 3. Number of Korean musical productions performed in major Asian countries

\begin{tabular}{l|l|l}
\multicolumn{1}{c}{ Country } & \multicolumn{1}{l}{ Year } & $\begin{array}{l}\text { Number of } \\
\text { Productions }\end{array}$ \\
\hline \multirow{4}{*}{ Japan } & 2012 & 10 \\
\cline { 2 - 3 } & 2013 & 21 \\
\cline { 2 - 3 } & 2014 & 9 \\
\hline \multirow{3}{*}{ China } & 2012 & 3 \\
\cline { 2 - 3 } & 2013 & 7 \\
\cline { 2 - 3 } Taiwan & 2014 & 3 \\
\hline \multirow{2}{*}{ Thailand } & 2014 & 2 \\
\hline Singapore & 2012 & 1 \\
\hline Total & 2013 & 1 \\
\hline \multirow{2}{*}{\begin{tabular}{l} 
Ty \\
\cline { 2 - 3 }
\end{tabular}} & 2012 & 59 \\
\hline
\end{tabular}

To examine in more detail, the current status of Korean musical or nonverbal productions in major Asian countries from 2012 to 2014 are shown in Table 3. Over the three-year period, 42 productions had 59 runs in these countries. Six of the 
productions were foreign musicals produced in Korea under license, which later held a tour or sold performing rights to Japan and China. Jack the Ripper, The Three Musketeers, and Thrill Me toured in Japan, and the performing rights for Notre Dame de Paris and Elisabeth were sold to China. The cases where licensed foreign musicals were introduced to Japan's larger licensed musical theater market via Korea happens when Japanese production companies wish to use the Korean market as a way to predict the musical's potential for success in the Japanese market.

From 2012 to 2014,29 Korean musicals in 40 cases were performed in Japan, and 11 musicals in 13 cases made their way to China. Japan has a more developed infrastructure for musical theater but shows a higher proportion of licensed musicals and slower development of original musicals created in Japan. Among all musical productions in Japan, licensed musicals account for 90\% of the market sales. Japan's largest musical production company, Shiki, operates ten exclusives theaters which concentrate on running licensed shows. Shiki had attempted to enter the Korean market in 2004 but folded its plans when it met with the strong opposition from the Korean performing arts scene. In 2006, Shiki was able to enter the Korean market by holding a one-year run of The Lion King under license in Korea, but the result was a deficit of 3.7 billion won. Since then, Shiki has shown no interest in the Korean market.

Other than Shiki, no other Japanese musical production company has shown interest in entering the Korean market due to its exclusivist attitude toward Japanese culture. As Japan has a population of more than 120 million, Japanese musical production companies tend to focus on their domestic market rather than seeking entry into overseas markets. On the other hand, Korean musical theater must advance into the Japanese market to survive in the saturated domestic market. The Chinese market has great potential, but for now, the largest overseas market in Asia for Korea is Japan. Moreover, due to Japan's historical conflicts with many Asian countries, Japanese culture often faces difficulties in entering overseas markets. As Korea is almost the only Asian country other than Japan with suitable contents and the infrastructure necessary for advancing abroad in the field of performing arts, Korean productions have shown a stronger tendency to seek entry into the global market more actively than those of Japan.

Korean musicals made their first appearance in Japan in 2007 through selling the license of Singing in the Rain. Since then, the demand for Korean musicals in Japan has largely been an outcome of the Korean Wave. Japanese promoters, knowing that fans of the Korean Wave respond to musicals with K-pop stars, imported Korean musicals to Japan. "Korean musical productions, which had only sporadically run in Japan, started to be performed in Japan in full-fledge through the invitation of Japanese production and entertainment companies from 2011" (Hur 40). CJ E\&M 
established an exclusive theater for Asian musicals in Tokyo jointly with Amuse, a Japanese entertainment company, where eight original Korean musical productions have been performed. However, their strategy of casting talented actors rather than idols or Korean Wave stars and focusing on artistic quality proved a failure, and the theater closed down in February 2014. Their case exemplifies the heavy dependence of Korean musicals in Japan on Korean Wave stars today. For Korean musicals to create their own Korean Wave in Japan without relying on the Korean Wave of other genres, what is needed is to develop original, high-quality contents that can fill in the gap that remains in the Japanese market due to the lack of Japanmade musicals.

In the case of China, the importance of the culture industry was officially recognized for the first time in the country's 1oth Five Year Plan for National Economic and Social Development (2001-2005). The 11th Five Year Plan (20062010) that followed placed efforts on improving the culture industry's infrastructure, fostering the market for cultural contents, and promoting creative activities. The Chinese government further announced its plan to nurture the culture industry as one of the country's leading industries for the development of the national economy in the 12th Five Year Plan (2011-2015) and presented specific goals for establishing a modern cultural market system and strengthening China's soft power in the 13th Five Year Plan (Lee, "A study on the China" 77). Despite such efforts, however, the assessment is that industrialization is still in progress for China's culture industry when looking at just the performing arts sector. Still, the demand for cultural contents is expanding in China, whose per capita GDP has surpassed US\$ 8,0oo in 2017, and the performing arts industry which has been developing with Beijing, Shanghai, and Guangzhou as its centers is expected to create a 4 trillion Korean won market by 2020 (KCCA, Contents Industry Trend of China 16).

China's performing arts has been well-developed in terms of traditional theater which combines traditional music and drama but not so much in terms of modern dramatic theater. In short, although the demand and government support for the performing arts has been growing in China, the industry still lacks creative contents. Moreover, to cultivate its performing arts industry, China is faced with the need to acquire the know-how on creating and staging performing arts productions. In 2010, CJ E\&M established Ajuyeonchang Culture Development Corporation (ACDC) with Shanghai Orient Media Group Co., Ltd., the largest media group in China. ACDC acquired the license to perform Mamma Mia in China and adapted the CJ E\&M's production of Mamma Mia in Korea to match the taste of the Chinese audience. The show ran for 190 performances over a threemonth period in 2011 which brought in a 130,00o audience (Kim, "A Study" 97). In 2013, ACDC licensed Korean musical Finding Mr. Destiny and adapted it for China as Finding the First Love. The company co-produced Feast of the Princess in 2015 
and produced Thrill Me in Chinese under license in 2017. Many original Korean musicals such as Laundry, Bachelor's Vegetable Store, My Bucket List have been produced in China, but they have not enjoyed great success yet. Korea's musical comedy will be able to share the fruits of the development of Chinese performing arts by contributing to its growth through co-production, the sharing of planning and production know-how, and the exchange of performance-related technology and human resources.

Performances in China do not only target the Chinese market but are also foundations for exploring the market of Chinese-speaking regions including Hong Kong, Macao, Taiwan, and Singapore in the long run. The small populations of Hong Kong, Macao, and Singapore present unsuitable market conditions for the production of cultural contents and products, but their massive influx of tourists give them the potential to become hubs for of distributing the performing arts. Nonverbal performances, such as Nanta, Jump, and Bibop, and smaller spectacular musicals, such as Flying and Hwarang, have been exploring their potential for success in this region. As the ASEAN countries have yet to establish a foundation for their culture industry, international cultural exchange is a more appropriate form for approaching these countries rather than attempting to enter their markets directly. For Korea's performing arts industry to expand the Korean Wave formed by K-pop and drama, it will need to await this region's market to mature.

\section{CONCLUSION}

Korea's culture industry strengthened its domestic foundations from the 1990 on and expanded into the overseas market to create the international phenomenon called the Korean Wave from the late 1990s. The Korean Wave was the collaborative result of Korea's cultural industrialization and the changes in external conditions such as the normalization of Korea's diplomatic relations with China and the increase in Asia's consumption of cultural contents. The field of performing arts also showed similar trends of domestic industrialization and globalization, but Korea's performing arts has yet to gain a level of influence as the Korean Wave phenomenon created by Korea's TV drama or popular music. The Hallyu White Paper published by the Korea Foundation for International Cultural Exchange reviews the status of the global Korean Wave by category including TV shows, film, music, game, cartoon, fashion, beauty, food, but the performing arts were not even set as a part of its categories until 2014. That is, Korea's performing arts are at the beginning stage of overseas expansion with the help of the Korean Wave solidified by other cultural genres. 
For Korea's performing arts to create its own Korean Wave, it is not enough for Korea's performing arts industry to develop its creative capacity-what is also necessary is the industrialization of the culture industries in neighboring countries. This mechanism works through the same logic that entailed Korean performing arts scene to be industrialized for Korea to license Broadway productions. Performances require physical spaces in the form of performance halls. The transportation of the original work's human and material resources such as actors, staffs, stage set, and others leads to a rise in the production costs. Therefore, performances can only acquire marketability when there is a pre-existing performing arts infrastructure in the importing country. The necessity of an already-established infrastructure is a particularity of the performing arts that does not apply to other genres such as films, music, publications, and games and is an area that must be resolved for the international exchange of the performing arts.

As overseas audiences are unable to encounter original local productions, the productions need to be produced overseas through a medium that acts as a distribution channel. Even in the case of tour performances, and not licensed productions, such distribution channels are necessary. Korea's popular music and TV drama gave birth to the Korean Wave through their distribution via virtual spaces such as the Internet and YouTube, but as direct experience is essential in the case of the performing arts, the distribution method cannot but be completely different. Only by becoming China's partner in driving the industrialization of China's performing arts, a change which has just begun, will it be possible for Korea to create a Korean Wave of the performing arts centering on the Chinese-speaking regions.

Moreover, for Korea's performing arts industry to generate its own Korean Wave without resorting to that of other genres, the consistent production of original, high-quality performances is a must. To ensure the continuous creation of high-quality productions, Korea will need to consolidate the industrialization of its domestic performing arts industry. However, Korea's public producing houses and performing arts distribution network have not seen much development. Despite having Daehak-ro, a unique cultural hub of unprecedented creativity, without enhancements in production and distribution capacities, Korea will find it difficult to create high-quality performances that can enter the overseas market. The Korean Wave of the performing arts will arise through the strengthening of the industrialization of Korea's domestic performing arts and by leading the industrialization of the performing arts in other countries. 


\section{Works Cited}

2015 Survey on the Musical Comedy, Korea Arts Management Service, 2015.

2017 Survey on the Performing Art, Korea Arts Management Service, 2017.

2017 Hallyu White Paper, Korea Foundation for International Cultural Exchange, 2017.

Ahn, Sung Ah. “A Statistical Look at Daehak-ro's Theater Ecosystem," Academic Conference Proceedings of the Korean Society of Arts and Cultural Management, vol. 1, no. 1, 2012, pp. 1-45.

Cho, Boo Keun. "The History and Key Issues Concerning Policies on Cultural Diplomacy in East Asia." Journal of Art \& Cultural Management, no. 1, 2008, pp. 75-92.

Choi, Byeong-chun. "A Study on the Industrialization Strategy of Korea's Performing Arts Industry for Its Entry into the Global Market." Academic Proceedings of the 2004 Korea Research Association of International Commerce, 2004, pp. 85-114.

Choi, Won-Gun, and Byung-Jin Yim. "A Study on the Industrial History and Development of the Musical Theater in Korea." Business History, vol. 30, no. 3, 2015, pp. 35-56.

Hur, Eun-Young. A Study on the Supporting Policy for Oversea Expansion of Performance: Focused on Musicals. Korea Culture \& Tourism Institute, 2013.

Kim, Sang-Ug. "A Study on Overseas Expansion Supporting Strategies of Korean Creative Musical: Focusing on Asia." Journal of Culture Industry, vol.16, no.1, 2016, pp. 1-10.

Kim, Soo-Young. "A Study on the Expansion of Korea Musicals into Asia Market - Focus on China Musical Market." The Journal of Image and Cultural Contents, no. 9, 2015, pp. 91-105.

Korea Arts Management Service, http://www.gokams.or.kr.

Korea Creative Content Agency, Contents Industry Trend of China, no. 6, 2013.

Lee, Ji-Yoon. "A Study on the China Cultural Policy for Expansion about Korea Musical Industry into China." Journal of Culture Industry, vol. 17, no.1, 2017, p. 75-81.

Lee, Kang-Wuk. Analysis of International Tourism Demand Factors and their Impacts in Korea. Korea Culture \& Tourism Institute, 2017.

Lee, Young-Chan. Research on the Current State of Korean Theater Companies' International Exchange and Revitalization through 'Performing Arts Market in Seoul' (2005-2014): Focused on the Chosen Theater Companies by PAMS Choice. MA Thesis, Hanyang University, 2016.

Park, Byung-Sung. "What Happened in the Musical Theater in 2012." The Musical, Dec. 2012, pp. 44-48.

--. A Study on the Industrialization of Licensed Musicals in the 20oos, MA Thesis, Korea National University of Arts, 2015.

Report on the Future Strategy for the Arts Industry, Korea Art Management Service, 2017. 